\title{
The Effect of Exclusive Breastfeeding on Illness Frequency of The Baby
}

\author{
Rizki Amalia* \\ Universitas Nahdlatul Ulama Surabaya, Indonesia \\ *amalia24@unusa.ac.id
}

\begin{abstract}
Exclusive breastfeeding is the most suitable nutrient for babies for 0-6 months. In reality, exclusive breastfeeding is still far from the expected target. Meanwhile, it was still found that many numbers of ill babies visit. This study aims to find out the illness frequency difference between the 2 year ill babies who got exclusive breastfeeding and babies who did not get exclusive breastfeeding. This research was a retrospective analytical study. The population in this study was 2 year old babies in Wonokromo Health Center area which had 51 babies. The sample was taken by simple random sampling technique to 46 babies. The independent variable was breastfeeding, while the dependent variable was the illness frequency of 2 year ill babies in Wonokromo health center area. Data collection used questionnaire. To analyze the difference, it used the Mean Whitney Test with a significance level of $5 \%$. The result showed that the characteristic of respondents aged $\leq 20$ years was $17.39 \%, 21-30$ years was $60.87 \%, 31-40$ years was $19.57 \%$, and $41-50$ years was $2.17 \%$. Based on the educational background, those who had primary education were $8.69 \%$, those who had junior high school education were $26.09 \%$, those who had senior high school education were $60.87 \%$, and those who had college education were $4.35 \%$. While based on the employment, as a trader was $26.09 \%$, as a housewife was $45.65 \%$, as an entrepreneur $13.04 \%$, as a government employee was $6.52 \%$, as a private employee was $8.67 \%$. Those who gave exclusive breastfeeding were $32.61 \%$, those who did not give exclusive breastfeeding $67.39 \%$. The average number of illness frequency of 2 year ill babies was 5 times. After being analyzed, it was obtained that $\mathrm{p}=0.030$ Ho Ho was rejected and H1 was accepted. Based on the description above, it can be concluded that there is difference between the 2 year ill babies who got exclusive breastfeeding and babies who did not get exclusive breastfeeding. It means that exclusive breastfeeding can affect the illness frequency of baby. Therefore, it is recommended that breastfeeding mothers should give exclusive breastfeeding to their babies.
\end{abstract}

Keywords: Exclusive breastfeeding, Illness Frequency, Baby 


\section{STRADA Jurnal Ilmiah Kesehatan}

DOI: $10.30994 /$ sjik.v9i2.517

ISSN: 2252-3847 (print); 2614-350X (online)

Vol.9 No.2 November 2020 Page.1676-1679

\section{BACKGROUND}

Frequency Introduction Infant Mortality Rate (IMR) in Indonesia is caused by several factors, such as premature birth, neonatal infection, low nutrition, congenital defect, low breastfeeding rate soon after childbirth/early initiation of breastfeeding, and low exclusive breastfeeding for the first 6 months of life. early initiation of breastfeeding and exclusive breastfeeding play important roles in decreasing the infant mortality rate in Indonesia so that the target set by Millennium Development Goals (MDGs) in 2015 can be achieved (Ginanjar, 2008). Based on the preliminary survey on 20 children under five in Wonokromo Community Health Center, only 8 children received exclusive breastfeeding, whereas 12 children did not. In relation with morbidity rate in the last 1 month, among 8 children with exclusive breast milk, 5 children were healthy, 2 children were sick once, and 1 child was sick twice. Whilst, among 12 children without exclusive breast milk, 1 child was healthy, 6 children were sick once, 5 children were sick twice. The condition of sick children is affected by several factors, such as age, sex, hereditary, congenital defect, healthcare, sensitivity to diseases, sanitation, and environmental condition (Soetjiningsih, 2007). Children who often get sick may experience problems with nutritional intake in which the nutrition they need is not fulfilled well because the appetite usually decreases during sickness. The nutritional intake may also get disturbed, for instance when they have diarrhea or vomiting. Another effect is low weight gain resulting in problems with growth and development. Therefore, sick children need the correct treatments to decrease the morbidity and mortality rate. The government has done some efforts to decrease the mortality rate in children under five with Integrated Management of Childhood Illness (IMCI). IMCI was firstly introduced by WHO as a strategy to provide healthcare purposed to decrease the mortality and morbidity rate, as well as birth defect rate in babies and children under five in developing countries (Depkes RI, 2008). In addition, preventive efforts have been done early by promoting breastfeeding which is related indirectly with the health of babies and children under five. To increase the roles of breastfeeding, the breastfeeding promotion program, especially exclusive breastfeeding, should be prioritized because of its great effects on the nutritional and health status of children under five (Roesli, 2008). Based on the phenomena described above, this study was conducted to investigate breastfeeding which probably affects the morbidity in children under five. This study was purposed to prove the difference of disease frequency in two-year-old children with exclusive breastfeeding and without exclusive breastfeeding

\section{METHODS}

The method of this study was analytical survey to explore how and why the phenomena of health happen. It was purposed to analyze the difference of disease frequency in children aged 2 with and without exclusive breastfeeding. This study was designed to answer the research questions or examine the validity of hypothesis. In this study, the researcher used retrospective design. This study involved the two-year-old children found in Wonokromo Community Health Center as the population in which the samples were chosen as the respondents by using simple random sampling technique. Thedata were collected using questionnaires. The statistical analysis was done by using Mann-Whitney Test. This study was conducted in Wonokromo Community Health Center in January until June 2018. The independent variable was breastfeeding; whereas the dependent variable was disease frequency in the sick children aged 2. To analyze the difference of disease frequency, Mann-Whitney Test with the significance level of 5\% was used 


\section{STRADA Jurnal Ilmiah Kesehatan}

DOI: $10.30994 /$ sjik.v9i2.517

ISSN: 2252-3847 (print); 2614-350X (online)

Vol.9 No.2 November 2020 Page.1676-1679

\section{RESULT}

The results of this study conducted to 46 respondents showed that most of the mothers totaling 28 people (60.87\%) were $21-30$ years old. This is supported by the claim made by Hurlock (1998) in Nursalam and Pariani (2001) stating that growing older makes people think and act more rationally as resulted from the experiences and maturity of soul.

\section{DISCUSSION}

2018327 Most of the respondents totaling 28 mothers (60.87\%) graduated from senior high school so that they had an ability to correctly express the knowledge they have possessed. According to Nursalam and Pariani (2001), the higher the level of education possessed by an individual, the more easily they receive information. In other words, as the message receivers, they can prepare themselves to follow the process of communication. Most of the respondents totaling 21 mothers $(45.65 \%)$ were housewives who had more spare time than career women so that they could use their time to receive information independently. Based on the study conducted to 46 mothers, the results showed that only few of the two-year-old children totaling 15 children $(32.61 \%)$ received exclusive breastfeeding; and the average disease frequency was 5 times. While the average disease frequency in children who did not receive exclusive breastfeeding was 6 times. The result of normality test by using Kolmogorov-Smirnov test showed that the value of $p=0.021(p<0.05)$, and showed that the result of data distribution was non-normal. Therefore, non-parametric statistic test was done by using Mann-Whitney test. The result of the test showed that the value of $p=0.030$ which meant that $\mathrm{p}<0.05$ concluding that there was a difference of disease frequency in two-year-old children with and without exclusive breastfeeding. There are many factors affecting the breastfeeding behaviors, such as level of education, occupation, experience, psychological and environmental factors. The achievement target of exclusive breastfeeding was only $32.61 \%$ compared to $80 \%$ as expected. This result was possibly caused by some factors, namely parity, level of education, occupation, experiences, psychological and environmental factors. Breast milk can increase the immunity of children. Newborn babies receive immunoglobulin (body's immune substance) from their mothers through placenta. Yet, the level of immunity decreases rapidly soon after they are born. Babies produce their own body's immune substance sufficiently to provide protection at the age of 9-12 months. A similar study was conducted by Wariyatun (2009) showing that the average (mean) of the duration of breastfeeding was 111.14 days, the mean of disease frequency of diarrhea was 2.74 times, and the mean of disease frequency of upper respiratory tract infection (URTI) was 2.77 times. The study concluded that there was a low correlation between the duration of breastfeeding and diarrhea and upper respiratory tract infection in babies aged 6 months. Whilst, this study showed the difference of disease frequency in children aged 2 with and without exclusive breastfeeding.

\section{CONCLUSION}

This study revealed thatmost of the mothers $(97.83 \%)$ were adults; most of them $(60.87 \%)$ graduated from senior high school; and most of them $(45.65 \%)$ were housewives. Only few of the children $(32.61 \%)$ received exclusive breastfeeding, whereas $67.39 \%$ did not. Disease frequency experienced by the children aged 2 was averagely 5 times in 1 year. In conclusion, there was a significant difference of disease frequency in two-year-old children with and without exclusive breastfeeding 


\section{STRADA Jurnal Ilmiah Kesehatan}

DOI: $10.30994 /$ sjik.v9i2.517

ISSN: 2252-3847 (print); 2614-350X (online)

Vol.9 No.2 November 2020 Page.1676-1679

\section{REFERENCES}

Erlangga.Jusup, Lenny. 2008. Makanan Peningkat Daya Tahan Tubuh Bayi dan Balita. Jakarta: PT Gramedia Pustaka Utama.Kementerian Kesehatan R.I. 2010.

Profil Kesehatan Indonesia 2009. Jakarta: Kementerian Kesehatan Republik Indonesia.Bidang Peningkatan Kualitas Hidup Perempuan. 2008.

Pemberdayaan Perempuan Dalam Peningkatan Pemberian ASI.Jakarta: Kementerian Negara Pemberdayaan Perempuan R.I.Kartono, Kartini. 1986.

Psikologi Wanita Jilid II. Bandung: Alumni.Krisnatuti, Diah. 2002.

Menu Sehat Ibu Hamil dan Menyusui. Jakarta: Rineka Cipta.Krisnawati, Inti. 2008.

HealingFood for Kids. Jakarta: PT Gramedia Pustaka Utama.Kristiyansari, Weni. 2009.

ASI, Menyusui dan Sadari. Yogyakarta: Yoha Medika.Latipun. 2001.

Psikologi Konseling. Malang: Universitas Muhammadiyah.Nelson. 1992.

Ilmu Kesehatan Anak I. Jakarta: EGC.Notoatmodjo, S. 2005.

Metodologi Penelitian.Kesehatan. Jakarta: Rineka Cipta.Nursalam, Siti Pariani. 2001.

Pendekatan Praktis Metodologi Riset Keperawatan.Jakarta: CV Sagung Seto.Nursalam. 2003.

Konsep dan Penerapan Metodologi Penelitian Ilmu Keperawatan. Jakarta: Salemba Medika.. . 2008.

Konsep dan Penerapan Metodologi Penelitian Ilmu Keperawatan. Jakarta: Salemba Medika.Prabantini, Dwi. 2010.

A to Z Makanan pendamping ASI.Yogyakarta: CV Andi Offset.Purwanti, H.S. 2004.

Konsep Penerapan ASI eksklusif. Jakarta: EGC.Prasetyono, D.S. 2009.

Buku Pintar ASI eksklusif. Yogyakarta: Diva Press.Puskesmas Sidokerto. 2010.

Pedoman dan Perawatan Balita Agar Tumbuh Sehat dan Cerdas. Bandung : CV Nuansa Aulia.Roesli, U. 2004.

Mengenal ASI eksklusif.Jakarta: Trubus Agriwidya.Saleha, Sitti. 2009.

Asuhan Kebidanan Pada masa Nifas. Jakarta : Salemba Medika.Santoso, Singgih. 2006.

Menggunakan SPSS untuk Statistik non Parametrik. Jakarta: Gramedia.Santoso, Singgih. 2008.

Panduan Lengkap Menguasai SPSS 16. Jakarta: Gramedia.Setiadi. 2007.

Konsep\&Penulisan Riset Keperawatan. Yogyakarta: Graha Ilmu.Setiawati. 2008.

Pemberdayaan Perempuan Dalam Peningkatan Pemberian ASI. Jakarta : Kemenkes RI.Soetjiningsih. 1995.

Tumbuh Kembang Anak. Jakarta: EGC. . 1997. ASI Petunjuk Untuk Tenaga Kesehatan. Jakarta: EGC.Sugiyono. 2010.

Statistik untuk Penelitian. Jakarta: Alfabeta.Suradi, Rulina, dkk. 2007.

Manajemen Laktasi. Cetakan ke 3. Jakarta : Perinasia.Wariyatun. 2009.

Hubungan Lama Pemberian Air Susu Ibu dengan Frekuensi Sakit Diare dan ISPA Bayi Usia 6 Bulan di Kecamatan Dagangan. Karya Tulis Ilmiah, Program Studi DIII Kebidanan Kampus Magetan Poltekkes Surabaya, Mage 